\title{
STRUCTURAL MODELS IN TECHNICAL TEXTS AS A RESULT OF A LINGUISTIC-PRAGMATIC ANALYSIS
}

Typical structural models in technical language, their use in understanding, translating and producing technical texts as well as in technical language teaching, engineering and technology (word-formation, grammatical and syntactical structural models and their pragmatic-linguistic analysis). Comparison of typical linguistic structures in Slovak, German and English technical texts.

Key words: Technical language teaching, pragmatic-linguistic analysis of a technical text, structural model

\section{Introduction}

Technical texts as a form of technical and scientific communication nowadays are not only a communication tool of experts but they also affect communication of ordinary language users. Technical documentation, chemical composition of products, safety precautions for handling mechanisms and devices, working procedures, manuals, product parameters etc. best exemplify technical language used in technical texts.

The use of technologies in our everyday life brings about the fact that technical terminology and ordinary language overlap. This interaction concerns e.g. internet or mobile communication terminology, household or workplace equipment terminology, etc.

Requirements laid on various types of technical texts can be classified according to different points of view:

- from the point of view of a consumer; clarity, pertinence, comprehensiveness, informativeness and legibility is assumed, and

- from the point of view of a producer whose market-oriented criteria involve brevity and attraction.

Technical texts aimed at experts and specialists are less comprehensible to ordinary users and their most typical characteristics are professional expertise, terminology, more complex sentence structure.

Communication in the professional area is successful only on condition that all the individuals involved in the communication have mastered the inventory of technical terminology and have sufficient command of communication strategies of verbal and nonverbal nature.

Pekarovicova [1] lists the following prerequisites essential for communication in the technical area:
- "building of fundamental lexical and grammatical apparatus inevitable for verbal and non-verbal behaviour in specific communication situations denominated as technical and communication minimum (composed of inventory of frequent general expressions of categorial meaning),

- understanding of transformational and derivational possibilities of the Slovak language, adopting respective sentence structures and specific terminology relevant to the field of study."

Pekarovicova recommends creating information and communication base of technical texts by means of "technical communication models comprising word-formation, denomination and syntactical utterances for determination, description or classification of objects and phenomena or demonstrating relations in technical texts" $[1$, pp. 3-10].

A number of linguists have aimed their research at structural modelling of technical language:

A Slovak linguist Findra in his publication Stylistics deals with the analysis of scientific prose style along with the characteristics of "formal model structures" [2, p. 181].

Becker, the author of Fachdeutsch Technik, Metall-und Elektroberufe coursebooks series, refers to structural models typical of technical language as "logic structures". For the teaching process he suggests acquiring "structures" of definition, causality, working procedure etc. Technical phenomena and problems can be described, understood and solved provided we are capable of their linguistic reflection or understanding in logic structures [3, p. 6].

The issue of controlled language (kontrollierte Sprache) has captured interest of plenty of linguists engaged in linguistic research of technical texts and their typical structures. This version of the language is based on the specific textual models. Texts of this kind are simple in style, grammar and sentence structure and their vocab-

\footnotetext{
* Katarína Pankuchova, Andrea Gavlakova

Department of Foreign Languages, Faculty of Science, University of Zilina, Slovakia, E-mail: katarina.pankuchova@fpv.uniza.sk
} 
ulary focuses on particular areas (without polysemy, homonymy or synonymy). Production of a controlled language text has to comply with well-defined rules. Production of texts is governed by certain patterns elaborated by some companies to ensure not only certain standard and image but also definiteness and quality of their communication tool, unified terminology and comprehensible formulations in documents. This is the evidence of professionalisation of technical texts as a form of communication. This trend results from the need to make transparent important information about products and production processes. Comprehension of technical data and guidelines increases level of skills and safety in handling technologies. The effort to simplify the terminology to make it more accessible and unify the communication between a producer, a product and a consumer resulted in uniformity and defining linguistic requirements for elaborating technical documents Internal production technical documents as safety regulations, production guidelines etc. can be stated as an example of the aforementioned.

As far as instructional types of technical texts are concerned, their content and structure conform to specific requirements of a legal basis (Consumer Protection Act) and they are stipulated by directives and standards, e.g. in Germany "Richtlinie Technische Dokumentation" VDI 4500, "Erstellen von Anleitungen“ DIN ENIEC 62079, "Gebrauchsanweisung für verbraucherrelevante Produkte“ DIN V 66055 [4, p. 30].

Linguistic research of the technical language has developed over a period of time and apart from other things it concerned linguistic structures typical of a technical text:

From the diachronic perspective, primary phase of this research focused on the description of common specific features typical of a technical text in respective linguistic branches (morphology, lexis, stylistics). A German linguist Hoffman [5].

In his publication "Kommunikationsmittel Fachsprache" analysed and defined technical language from different perspectives: structural-systemic, lexical-terminological, functional linguistics, applied linguistics and translation. The Prague school of linguistics also conducted systematic research in stylistic distinction of a language inventory. The resulting theory of functional linguistics gave rise to further analysis of its applicability in the complex framework of technical languages.

The emphasis on the communication aspect of linguistic phenomena has moved the research of the technical language towards the search of prospective links between structural-systemic assessment of the language and socio-communicational effects of linguistic phenomena. Present linguistics tends to analyse the text not only as a mere process of linking words into certain syntactical and morphological relations. Presence of pragmatic aspect of the text helps create actual impact of linguistic discourse on the addressee. The role of pragmatics is to achieve certain impact or effect on the addressee by means of certain language utterances (intonation, phonology, morphology, or syntax) in certain situations [6].
Pragmatic aspect of a language utterance arises from the function of the language being an active communication tool, i.e. language utterances are used effectively in order to arouse interest of parties involved in the communication. It is thus a relation between an utterance and its user, or its meaning and effect. Assuming the language utterances used for exchanging information had no practical benefit, they would be meaningless.

Pragmatic analysis comprises both syntactic and semantic element. Pragmatics focuses on clarity and efficacy of linguistic and non-linguistic utterances with particular respect to methods and forms of consious selection of these utterances in order to achieve certain communication purpose.

A technical text is understood, produced, translated or interpreted well only on condition that the communicators employ their technical and communicative competences. This means that they match their professional knowledge of the subject matter of the communication with their language mastery (terminology and typical linguistic structures) as well as with their interpretational skills. Concord of content, form and function is hence achieved.

Summing up the knowledge of morphology, lexicology and syntax and relating it to its function, we come to an assumption that typical characteristics of a technical text are such language utterances whose most significant features are exactness and definiteness. Frequent occurrence of nouns is another typical attribute of technical texts. It is closely linked with notional-terminological denominations (in German mostly in the form of compounds) and with the propensity for syntactic condensation.

As Findra points out, a technical text is typical of its "nominal character" being the grounds of its "abstractness and notional brevity" [2].

Definiteness and accuracy are enhanced by the occurrence of language utterances performing various functions, e.g. modifiers of nouns - genitive (height of girder, intersection of axes, etc.), present participle (drilling torque), or past participle (welded material).

Another specific attribute of a technical text is its objectivity and neutrality. Passive constructions are typical of English and German technical texts. Descriptive function, commonly expressed by relative clauses, is also an exemplary feature of technical texts.

Selection of language utterances is closely linked with the function of the text. As far as functional aspect is concerned, technical or scientific texts can define, classify, describe objects or actions, provide instructions, compare, review, assess or explain.

The most remarkable feature of a technical text is the lexical predominance of terminology. Emphasis of the lexical aspect of the technical language brought about detailed study of terminology (Hoffmann Kommunikationsmittel Fachsprache) [5]. This resulted in focusing the primary interest on the analysis of word-formation. Technical terms endow technical texts characteristic features of conceptuality, neutrality, definiteness and accuracy. Word-forma- 
tion process also abides by certain structural models by means of which the following specific communication functions can be achieved:

- nominal, in order to denominate actions, mediators of actions, or properties of technical objects or quantities,

- descriptive, to describe properties of technical objects and phenomena etc.

The aim of this research was to gather frequently used model linguistic structures in Slovak, English and German technical texts whose common feature was pragmatic function. Based on this fact, they interrelated systemic and structural characteristics of technical texts with their function and impact on the addressee. By means of comparison of these model linguistic structures in several languages, valuable findings about technical texts as linguistic-pragmatic elements have been obtained.

Linguistic and pragmatic analysis of technical texts concentrated on the presence of word-formative, grammatical, syntactical structural models and their functions designated in this paper as nominal, descriptive and directive functions. The aforementioned functions attributed to the models certain word-formation processes.

\section{Examples of certain types of structural models}

\section{Morphological structural models in technical texts}

Morphology of the technical language distinguishes the process of constituting forms (Formbildung), namely formal representation of certain grammatical categories and word formation (Wortbildung) [7, p. 16]

\subsection{Word-formation structural models}

- with nominal function (resulting product is a noun)

a. denomination of activities or mediators (verbal nouns, nomina agentis, nomina instrumentalis)

\begin{tabular}{|l|l|l|l|}
\hline $\begin{array}{l}\text { infinitive } \\
\text { German/English }\end{array}$ & Slovak & German & English \\
\hline zvarat schweißen/ weld & zvaranie & das Schweißen & welding \\
\cline { 2 - 4 } & zvar & die Schweiße & weld \\
\cline { 2 - 4 } & zvarac & der Schweißer & welder \\
\cline { 2 - 4 } & zvaracka & die Schweißmaschine & welder \\
\hline
\end{tabular}

b. denomination of properties of technical objects or quantities/parameters

\begin{tabular}{|l|l|l|l|}
\hline $\begin{array}{l}\text { adjective } \\
\text { German/English }\end{array}$ & Slovak & German & English \\
\hline dlhy/ lang/ long & dlzka & die Länge & length \\
\hline siroky/ breit/ wide & sirka & die Breite & width \\
\hline vysoky/ hoch/ high & vyska & die Höhe & height \\
\hline hlboky/ tief/ deep & hlbka & die Tiefe & Depth \\
\hline pevny/ fest/ strong & pevnost & die Festigkeit & strength \\
\hline
\end{tabular}

- with descriptive function (adjective as a result)

1. description of properties of technical objects

\begin{tabular}{|l|l|l|l|}
\hline & Slovak & German & English \\
\hline property & bezolovnaty & bleifrei & unleaded, lead-free \\
\hline resistance & ohnovzdorny & feuerfest, feuersicher & fire-proof \\
\cline { 2 - 4 } & vzduchotesny & luftdicht & airtight, air-proof \\
\hline ability & tvarovatelny & verformbar & shapable \\
\hline
\end{tabular}

\subsection{Grammatical structural models}

- with attributive function of nouns, the purpose of the language utterance is to provide more specific and accurate characteristics [7, p. 21].

\begin{tabular}{|l|l|l|l|}
\hline Gram. form & Slovak & German & English \\
\hline Genitive & rychlost lietadla & $\begin{array}{l}\text { Geschwindigkeit des } \\
\text { Flugzeuges }\end{array}$ & $\begin{array}{l}\text { velocity of air- } \\
\text { craft }\end{array}$ \\
\hline $\begin{array}{l}\text { Present par- } \\
\text { ticiple }\end{array}$ & $\begin{array}{l}\text { pohybujuci sa } \\
\text { prvok }\end{array}$ & $\begin{array}{l}\text { hin- und hergehendes } \\
\text { Element }\end{array}$ & moving part \\
\hline
\end{tabular}

2. Syntactic structural models

These generally include sentence structures

- with directive function

\begin{tabular}{|l|l|l|l|}
\hline Function & Slovak & German & English \\
\hline $\begin{array}{l}\text { Necessity/ } \\
\text { obligation: }\end{array}$ & $\begin{array}{l}\text { znecisteny filter } \\
\text { treba (ma sa) } \\
\text { ihned vycistit. }\end{array}$ & $\begin{array}{l}\text { Das schmutzige } \\
\text { Filter ist sofort zu } \\
\text { reinigen. }\end{array}$ & $\begin{array}{l}\text { A dirty filter } \\
\text { needs cleaning. }\end{array}$ \\
\hline Possibility: & $\begin{array}{l}\text { znecisteny filter sa } \\
\text { da lahko vycistit. }\end{array}$ & $\begin{array}{l}\text { Das schmutzige } \\
\text { Filter ist leicht zu } \\
\text { reinigen. }\end{array}$ & $\begin{array}{l}\text { A dirty filter is } \\
\text { easy to clean. }\end{array}$ \\
\hline Prohibition: & $\begin{array}{l}\text { znecisteny filter sa } \\
\text { nesmie pouzivat. }\end{array}$ & $\begin{array}{l}\text { Das schmutzige } \\
\text { Filter ist nicht zu } \\
\text { benutzen. }\end{array}$ & $\begin{array}{l}\text { A dirty filter must } \\
\text { not be used. }\end{array}$ \\
\hline
\end{tabular}

- with imperative function

\begin{tabular}{|l|l|l|l|}
\hline Function & Slovak & German & English \\
\hline \multirow{2}{*}{ Imperative: } & $\begin{array}{l}\text { Dodrziavajte } \\
\text { normy! }\end{array}$ & $\begin{array}{l}\text { Halten Sie die } \\
\text { Normen ein! }\end{array}$ & Keep the norms! \\
\cline { 3 - 4 } & $\begin{array}{l}\text { Die Normen } \\
\text { einhalten! }\end{array}$ & $\begin{array}{l}\text { Caution! } \\
\text { Attention! }\end{array}$ \\
\hline Appeal: & Pozor! Dolezite! & Vorsich! Wichtig! & \\
\hline
\end{tabular}

- with comparative function

\begin{tabular}{|l|l|l|l|}
\hline Comparison & Slovak & German & English \\
\hline properties & $\begin{array}{l}\text { X je vacsie ako Y. } \\
\text { Y je mensie ako X. }\end{array}$ & $\begin{array}{l}\text { X ist großer als Y. } \\
\text { Y ist kleiner als X. }\end{array}$ & $\begin{array}{l}\text { X is greater than } \\
\text { Y. Y is smaller } \\
\text { than X. }\end{array}$ \\
\hline
\end{tabular}




\begin{tabular}{|l|l|l|l|}
\hline measures & $\begin{array}{l}\text { Cim je X vacsie, } \\
\text { tym je mensie Y. }\end{array}$ & $\begin{array}{l}\text { Je großer X ist, } \\
\text { um so (desto) } \\
\text { kleiner ist Y. }\end{array}$ & $\begin{array}{l}\text { The greater X (is), } \\
\text { the smaller Y (is). }\end{array}$ \\
\hline conditions & $\begin{array}{l}\text { Ak sa zvacsuje X, } \\
\text { zmensuje sa Y }\end{array}$ & $\begin{array}{l}\text { Vergroßert sich } \\
\text { X, so verkleinert } \\
\text { sich Y. }\end{array}$ & $\begin{array}{l}\text { If we increase X, } \\
\text { Y decreases.0 }\end{array}$ \\
\hline $\begin{array}{l}\text { conditional } \\
\text { relations }\end{array}$ & $\begin{array}{l}\text { So zvacsovanim } \\
\text { X sa zmensuje Y. }\end{array}$ & $\begin{array}{l}\text { Mit Vergroßerung } \\
\text { des X verkleinert } \\
\text { sich das Y. }\end{array}$ & $\begin{array}{l}\text { Increasing X will } \\
\text { result in } \\
\text { decreasing Y. }\end{array}$ \\
\hline
\end{tabular}

Technical texts not only vary in subject matter based on a particular professional area (mechanical engineering, power engineering, telecommunications, information technologies, civil engineering etc.) but also in the level of professional expertise which affects terminology density as well as sentence structure. The degree of professional expertise of a technical text is dependent on the target reader. Instructional technical texts designed for consumers of technical products ought to be simple, comprehensible and clear, supplemented by non-verbal textual elements like images, photographs, diagrams, tables, charts, etc. Latest information technologies enable us to use sound simulations, animated pictures, videos, etc. Safety cautions are guiding, bare, brief, urgent and comprehensible texts generally reinforced by warning signs (Inflammable! Poison! High voltage danger)

Technical texts designed for specialists or experts are more elaborated, saturated with technical terms, and have more complex sentence structure, which makes them less comprehensible to ordinary consumers/readers. Hoffmann [5, p. 33] made a division of technical texts according to the level of abstraction into scientific texts ranging from theoretical, experimental and applied science, and into technical texts of material production with lower level of abstraction and consumer technical texts with the lowest level of abstraction.

The incursion of technical language into everyday life is often felt by ordinary users as a communication hindrance as they usually find technical language unfamiliar and incomprehensible. This applies to various types of texts, e.g. user manuals, composition of chemical substances, safety warnings etc. Therefore, technical information often includes images, photographs, diagrams etc. in order to reinforce perception of the technical text. Complex sentence structures and high terminology standard may be viewed as a barrier for a smooth communication. Understanding the structures of the technical language in relation to the function of the text leads to refining language competences and perceiving the technical text correctly.

Structural models may become useful tools for

- making the process of technical language teaching at universities more efficient in order to acquire more profound knowledge in the professional area

- improving skills of technical texts comprehension

- translating technical texts,

- production of technical texts in foreign languages.

Short technical texts such as instruction manuals or safety cautions accompany products on the market and in compliance with the regulations of the European Union they must be translated into several languages. Numerous international corporations and producers that sell and provide their products and services in Slovakia are also obliged to elaborate manuals or working instructions in foreign languages. Active knowledge of a foreign technical language is therefore a necessity. Many companies require sufficient profficiency of a technical language apart from their internal "controlled languages". "At present a growing number of international companies has brought about the demand for language learning. Sufficient command of a foreign language has become a prerequisite for a success on the labour market" [8, p. 242]. Structural models can enhance the process of mastering linguistic and technical competences in a foreign language for ordinary users as well as in a professional field.

\section{References}

[1] PeKarovicova, J.: Linguistic and Didactic Aspects of Professional Communication (in Slovak), Slovenska rec, 65, c.1, pp. 3-10, 2000 http://www.juls.savba.sk/sr/2000/1/sr2000_1.html

[2] FINDRA, J.: Stylistics of the Slovak Language (in Slovak), Martin, Osveta, p. 232, ISBN 80-8063-142-5, 2004

[3] BECKER, N.: Fachdeutsch Technik, Metall-und Elektroberufe, Lehrerheft, Munchen, Max Hueber Verlag, p. 53, ISBN, 1983

[4] LEY, M.: Kontrollierte Sprachen, 2006 http://geb.uni-giessen.de//geb/volltexte/2006/2713/

[5] HOFFMANN, L.: Kommunikationsmittel Fachsprache, Berlin, Akademie-Verlag Berlin, p. 307, ISBN 3-05-000417-7, 1987

[6] Sprachwissenschaft, Einleitung http://de.encarta.msn.com//encyclopedia_761594370/Sprachwissenschaft.html

[7] BUHLMANN, R., FEARNS A.: Handbuch des Fremdsprachenunterrichts, Munchen, Langenscheidt KG, p. 400, ISBN 3-468-49435-1, 1987

[8] VAVRUSOVA, B.: Foreign Language Teaching under Specific Conditions in a Company (in Slovak), Cizi jazyky v kontextu multikulturni Evropy, Usti nad Labem, Univ. J. E. Purkyne, Usti nad Labem, ISBN 978-80-7414-074-7 2008. 